\author{
Abstracta Iranica \\ Abstracta Iranica Revue bibliographique pour le domaine irano-aryen \\ Volume 42-43 | 2021 \\ Comptes rendus des publications de 2019-2020
}

\title{
Matteo De Chiara, Daniel Septfonds. Le verbe pashto : Parcours d'un territoire du verbe simple à la locution verbale
}

\section{Agnes Korn}

\section{(2) OpenEdition \\ 12 Journals}

Electronic version

URL: https://journals.openedition.org/abstractairanica/53077

DOI: 10.4000/abstractairanica.53077

ISSN: 1961-960X

Publisher:

CNRS (UMR 7528 Mondes iraniens et indiens), Éditions de l'IFRI

\section{Electronic reference}

Agnes Korn, "Matteo De Chiara, Daniel Septfonds. Le verbe pashto : Parcours d'un territoire du verbe simple à la locution verbale", Abstracta Iranica [Online], Volume 42-43 | 2021, document 6, Online since 30 December 2021, connection on 14 December 2022. URL: http://journals.openedition.org/ abstractairanica/53077 ; DOI: https://doi.org/10.4000/abstractairanica.53077

This text was automatically generated on 14 December 2022.

All rights reserved 


\title{
Matteo De Chiara, Daniel Septfonds. Le verbe pashto: Parcours d'un territoire du verbe simple à la locution verbale
}

\author{
Agnes Korn
}

\section{REFERENCES}

Matteo De Chiara, Daniel Septfonds. Le verbe pashto : Parcours d'un territoire du verbe simple à la locution verbale. Wiesbaden: Reichert Verlag, 2019, 176 p. (Beiträge zur Iranistik 43)

1 The present book presents the verbal system of Pashto, focussing on the simple verbs. It is obvious that the background for the present work is the two authors' excellent knowledge of and decades-long acquaintance with Pashto. Nevertheless, the data for the present works comes chiefly from dictionaries, particularly the Pashto-Russian dictionary by Aslanov (1966) and the 4-vol. Pashto-Pashto Descriptive Dictionary published in 2005 by the Academy of Science of Afghanistan. These data are completed by an oral corpus collected by De Chiara and Septfonds and, where necessary, by interrogating native speakers.

2 The work is composed of four parts. The first one contains eight chapters on the verbal system of Pashto. It sets out with chapters 1. and 2. laying out the diverse terminologies used in the present work and the basic facts of the Pashto verbal system; some of the latter are to be expected from the viewpoint of other Iranian languages while others are not.

Chapter 3. presents a summary of differences among the Pashto dialects. Indeed, one of the strong points of the present work is that it consistently takes dialectal divergences into account instead of describing a (somewhat artificial) standard language. Another 
important methodological principle is to consistently distinguish verbs and meanings attested in examples from those (which are not rare) that seem to be obsolete meanings or verbs not backed with any examples.

4 The following chapters (4.-8.) deal with the various types of verbs. One major distinction is that between simple verbs and complex predicates (combinations of a noun or adjective and a so-called "light verb"), which are - as in Persian and many other Iranian languages - in the vast majority of cases the only way to express a given verbal concept, while the simple verbs are a closed class (i.e. not productive any more). There are also verbs combined with prefixes and denominative verbs (usually with the suffixes intransitive -ed-, transitive -aw-) and verbs built with the verbalisers kawəl/krəl 'to do' and kedəl/šwəl 'become'. The authors also include

processes of analogy and generalisation (quite often limited to some dialect(s)) which result in additional variation among the dialects.

6 Appendix 1 (p. 87-96) presents the pronouns, pronominal clitics, verbal endings and other inflectional prefixes.

7 The second centrepiece of the work (besides the survey of the verbal system in chapters 1 to 8 ) is the Appendix 2 (p. 97-150), which contains "Fiches détaillés", viz. a presentation of the simple verbs. Each entry contains dialectal variants and meanings found in dictionaries and other sources, followed by its inflexion and examples.

8 The volume concludes with indexes (p. 151-162), a short glossary of terms employed and the references.

9 Together with the second volume (Le verbe simple en pashto : État des lieux), which will be published in early 2022 as vol. 47 of the same series, the present work constitutes a milestone in the description of the Pashto language.

\section{AUTHORS}

\section{AGNES KORN}

CNRS, CeRMI, Paris 